DIGITAL COMMONS
@ UNIVERSITY OF SOUTH FLORIDA

Volume 1

Issue 1 Volume 1 (2011): Women's Poetry

\section{ABO: Interactive Journal for Women in the Arts, 1640-1830}

2011

\title{
Hearing Eighteenth-Century Occasional Poetry by and about Women: Swift and Barbauld
}

\author{
Elizabeth Kraft \\ University of Georgia, ekraft@uga.edu
}

Follow this and additional works at: https://digitalcommons.usf.edu/abo

Part of the Dramatic Literature, Criticism and Theory Commons, Educational Methods Commons, Feminist, Gender, and Sexuality Studies Commons, and the Literature in English, British Isles Commons

\section{Recommended Citation}

Kraft, Elizabeth (2011) "Hearing Eighteenth-Century Occasional Poetry by and about Women: Swift and Barbauld," ABO: Interactive Journal for Women in the Arts, 1640-1830: Vol.1: Iss.1, Article 6. http://dx.doi.org/10.5038/2157-7129.1.1.5

Available at: https://digitalcommons.usf.edu/abo/vol1/iss1/6

This Pedagogy is brought to you for free and open access by Digital Commons @ University of South Florida. It has been accepted for inclusion in ABO: Interactive Journal for Women in the Arts, 1640-1830 by an authorized administrator of Digital Commons @ University of South Florida. For more information, please contact digitalcommons@usf.edu. 


\section{Hearing Eighteenth-Century Occasional Poetry by and about Women: Swift and Barbauld}

\section{Keywords}

Anna Letitia Barbauld, Esther Johnson, ethics, gender, Jonathan Swift, Joseph Priestley, media, occasional poems, poetry, reading aloud, Stella

\section{Creative Commons License}

(c) $($ ) $\Theta$

This work is licensed under a Creative Commons Attribution-No Derivative Works 3.0 License. 
To read ethically, we must resist the impulse to impose our own values on the literature of the past (or even the present). Such an approach to reading, never easy, can be more complicated than usual when attempted in the service of occasional poetry-poetry written to a specific occurrence, often to a specific person or audience-and ethical reading can be further challenged when gender roles come into play. In tribute to the "occasion" of being asked to write an essay for Aphra Behn Online (i.e, the publication of British Women Poets of the Long Eighteenth Century, edited by Paula Backscheider and Catherine Ingrassia), I will discuss two eighteenthcentury occasional poems in which a speaker of one gender addresses a friend of the other gender: Swift's 1719 birthday poem to Stella and Anna Letitia Barbauld's “The Mouse’s Petition” written to her friend Joseph Priestley.

In this essay, I will suggest that our reading of each poem depends upon our "hearing" the poem as it must have "sounded" in its original context. I will further argue that the best way to do that is to read the poem aloud or to perform it, not in our own voice, but in the voice of the text's speaker. Defining my approach is insight offered by Backscheider in an earlier work, EighteenthCentury Women Poets and their Poetry. She notes that "[r]eading aloud was a major social and domestic activity" in the long eighteenth century (12). Many of the poems that found their way into print "were short and topical and delivered a familiar experience or emotion in simple language" (12). To achieve an ethical performance of any poem is to try to recapture that original voicing. And to do so, we must listen and resist the temptation to "overhear," in two senses of the word - to over-interpret and to hear as though we are eavesdropping. Both approaches to "hearing" in "life" produce misunderstandings; the same can be said of art. ${ }^{1}$

This essay is pedagogical in focus in two ways. First, it is a time-honored classroom strategy to read brief poems or parts of poems aloud to convey the beauty of poetic language with the correct emphases and intonations. However, many of us (myself included) rely on our love for the particular work to fund that moment. I do not think many of us "prepare" the poems we perform, but we would be wise to do so. This essay will argue that point. Additionally, our preparation for any given performance of a poem can model for students the level of research and thought necessary to "give voice" to eighteenth-century occasional poetry. The following discussions are offered, therefore, as student guides as well as collegial advice. I tested this approach in an Honors Introduction to Poetry course in which students were asked to prepare an oral reading of a poem. In setting up the assignment for them, I shared the Swift and Barbauld poems and the rationales and analyses I include below. Their own readings and explanations took about fifteen minutes per student. My class was relatively small, so we could thoroughly discuss each student's decisions and the resulting performance. I did not require a written essay, though, certainly, the assignment could be modified in that direction, particularly with poems that will not open themselves fully without some historical contextualization (thus requiring a good bit of research on the student's part).

My own understanding of the Swift and Barbauld poems I chose to prepare depended on significant biographical research regarding the addressee as well as the poet in question. Indeed, I felt invited by each poet to undertake some scrutiny of the person to whom he or she spoke as the identity of each addressee was a primary part of the poem's strategy and appeal. While it is true that each poem was generated in private circumstances characterized by intimate conversation signaled by distinct and pervasive traces of orality and domesticity, each poem also 
had a print life early on (supervised by the poet). As such, each had an original public audience that experienced the poem as quoted material or material overheard. In other words, the fact that the poems were printed by the authors (Swift's in his 1735 Poems on Several Occasions and Barbauld's in her 1772 Poems, published under her maiden name Anna Letitia Aikin) evidences the authors' desire to be heard beyond the first audience but with the first audience in mind.

Redemption of meaning (to allude to Stanley Cavell's term for ethical reading) of each of these poems has proven difficult for "eavesdroppers" and interpreters due to controversies surrounding the identities of Esther Johnson and Joseph Priestley. ${ }^{2}$ In other words, while the poems demand that we discover something of the identity of the addressees, the biography of each has impeded our understanding to some degree. In Stella's case, we are troubled with questions and speculations. Was Stella, as Samuel Johnson portrayed her, Swift's secret wife, living in "sorrowful resentment ... under the tyranny of him, by whom she was in the highest degree loved and honoured"? (336) $)^{3}$ According to Johnson, the marriage took place in 1716, three years before the poem in question. By 1719, Esther Vanhomrigh was a part of Swift's life as well; she was living in Dublin, pining for (and sometimes enjoying) Swift's company to Stella's chagrin. Do these biographical details matter? If we think of them and credit them, they certainly color the poem.

The controversy surrounding “The Mouse's Petition” has very little to do with the (literally) incendiary cultural status Priestley would earn eventually by his strongly expressed views on religious dissent and revolution. In 1772, events surrounding the Birmingham Riots and their aftermath (1791-94) were far in the future and Priestley himself a highly regarded natural scientist, materialist philosopher, educator, dissenting minister, and religious historian. Yet Anna Aikin's poem touched a new, unexpected nerve in some readers of her day and more of our day in which the nerve is no longer new but still quite raw. I refer, of course, to the sensibilities of those in the "animal rights" movement—not an organized movement by any means in 1772, but an incipient idea awaiting the voice some thought they heard in "The Mouse's Petition." The poet's distress at the eager reception of her poem as an indictment of her friend's cruelty to animals (an opinion expressed by the reviewers of both the Critical Review and the Monthly Review) led her to add a note to the 1773 version of the poem:

The Author is concerned to find, that what was intended as the petition of mercy against justice, has been construed as the plea of humanity against cruelty. She is certain that cruelty could never be apprehended from the Gentleman to whom this is addressed; and the poor animal would have suffered more as the victim of domestic economy, than of philosophical curiosity. $(245 n)^{4}$

Anna Aikin, like one of her favorite novelists, Samuel Richardson, seems to feel authorial intent should carry more weight than it did in her own day, even before the New Critics deemed it a fallacy.

Without denying the fallaciousness of a focus on "authorial intent," I think it reasonable to assume that the two poems under consideration are not meant to hurt, insult, or distress the intended private audience (Stella and Priestley respectively). ${ }^{5}$ Nor do I believe the works are meant to discredit either those individuals or the poets themselves with the intended public 
audience with which they are shared in the first place (the initial readership of the published poems) or the assuredly-desired public readership of futurity. It is always possible, of course, that an author says more than he or she sets out to say or reveals more than she or he means to reveal. But to assume as much is going too far; if there are hidden meanings and unconscious intentions, the texts themselves will reveal as much under careful consideration. We need to hear the poems as living language. We need to return the words on the page to the sound of a human voice.

There is an increasing awareness that poetry in general pleases best and means most clearly when it is heard. This idea lies behind both the University of Maryland's project Poets on Poets and the University of Pennsylvania's Center for Programs in Contemporary Writing's PennSound. I first heard of the latter at the American Society for Eighteenth-Century Studies 2007 annual meeting which was held in Atlanta, Georgia. In commenting on a panel having to do with Defoe's poetry, John Richetti bemoaned the lost art of poetry recitation and drew our attention to the PennSoundwebsite and the program's dedication to reviving this aspect of our literary heritage. ${ }^{6}$ The site features contemporary poets reading and discussing their own poems as well as literary scholars reading the poems of “classic” writers. The University of Maryland's website is devoted to contemporary poets' oral presentation (and interpretation) of Romantic poetry. Poets on Poets includes a prefatory essay by Jerome McGann entitled "Recitation Considered as a Fine Art.” Here, he describes the art and value of poetic performance:

[F]orget about the meanings, they come along for the ride (they come with the territory). The poem is a musical score written in our mother tongue. Our bodies are the instruments it was made for .... .

The poem will obey if you pay attention to what you're doing. Its mechanisms aren't difficult, even if they are amazingly flexible. They are as natural to us as speaking and singing ....

The basic structure is like a double helix — one strand is linguistic — a syntax and a semantics - the other is prosodic, made of rhythmical and acoustic units (metre and rhyme). We practice to discover their synchrony. The two play off each other, and while every poem permits a personal inflection of its elements, your freedom is constrained. That constraint is telling you to pay attention to what you're doing.

When you set out to perform a poem, you don’t proceed willy-nilly. You try it out and test its possibilities. There will always be multiple possibilities.

Eventually, in the act itself, you'll have to make a performance decision. When you do that you'll have something else to look at and think about. What was good about what you did, what wasn't. And so you can begin again.

In other words, McGann encourages us to allow ourselves to be instructed by the poem, deciding word by word, line by line, how best the verses sound. If we say the words as they asked to be voiced, we will discover the meaning of the poem. As he points out, however, there are always multiple possibilities. Any individual reader will make certain decisions based on presuppositions about language itself. The more we know, the better our choices. From a student's point of view, this need for knowledge can seem intimidating, but we all know 
something about life by the time we come to the reading of poetry. We begin with what we do know, and if the poem puzzles us, we try to learn more.

John Richetti's is the voice we hear reading the eighteenth-century selections on PennSound, and among the works he chose to record is Swift's first birthday poem to Esther Johnson, his friend and companion whom he called Stella.

“Stella’s Birthday” (1719)

Stella this day is thirty-four,

(We shan't dispute a year or more:)

However, Stella, be not troubled,

Although thy size and years are doubled,

Since first I saw thee at sixteen,

The brightest virgin on the green.

So little is thy form declin'd;

Made up so largely in thy mind.

Oh, would it please the gods to split

Thy beauty, size, and years, and wit,

No age could furnish out a pair

Of nymphs so graceful, wise, and fair:

With half the lustre of your eyes,

With half your wit, your years, and size:

And then, before it grew too late,

How should I beg of gentle fate,

(That either nymph might have her swain,)

To split my worship too in twain. (1-18)

[Click here to listen to John Richetti's reading of "Stella's Birthday" on PennSound.]

Listening to Richetti’s reading, we hear what Louise Barnett has called the "intimate and quotidian tone” of teasing affection that characterizes all of Swift's addresses to Stella (28). We also get the sense of "occasion" as the performance begins with a public announcement and moves to a personal address. True "hearing," however, depends on our performing the poem ourselves and paying attention to the poem's "possibilities” (McGann). In the performance we become speaker, listener, author, reader, and ultimately "poem.”

\section{Preparing to Perform “Stella's Birthday, 1719”}

I will now describe my own experience of preparing to perform this poem. I undertook this project when a sudden cancellation opened a space on the English III panel at the South Atlantic Modern Language Association. Patricia Hamilton was the chair of the session that year. Her topic was “The Pleasures of the (Long) Eighteenth Century” and, as I had planned already to attend the meeting (held in Louisville), I offered to step into the gap. I did so in order to help out, it is true, but also in order to engage in the activity recommended by PennSound and Poets on 
Poets: reciting eighteenth-century verse for others to hear and appreciate. My presentation addressed the process of preparation and demonstrated the end result.

To prepare for this recitation, I began by spending about twenty-four hours with the words, not struggling to understand, but letting the words carry me along. I had always imagined the birthday poems as written tributes-birthday cards, eighteenth-century style. I imagined Stella receiving her yearly missives and reading them, as I first read them, silently to herself. Paying close attention to the actual words of this poem, though, I recognized a public occasion; I began to hear the poem as a speech, not a letter, with Swift toasting the birthday girl, perhaps at a celebratory dinner. The beginning of the poem certainly has a festive, public tone: "Stella this day is thirty-four, / (We shan’t dispute a year or more).” Here, in my rendition, the speaker would pause for laughter or at least a smile from Stella who was in 1719 actually thirty-eight years old, a fact which Swift certainly knew since the prose account he wrote of her life specifically cites the date of her birth as March 13, 1681 ("Death" 227).

After raising his glass and paying Stella the deft compliment of subtracting years from her age, the speaker then addresses the honoree: "However, Stella, be not troubled, / Although thy size and years are doubled, / Since I first saw thee at sixteen.” Sixteen? Swift first saw Stella when she was a child of eight. Surely all their acquaintances knew their story. She certainly did. Why is he pretending that he first saw her at sixteen?

Pondering that question, I decided I would read the line ironically, and, perhaps I would hesitate between six and teen, bowing to two aspects of the "truth" of Swift and Stella's long friendship. The fact is that in 1694 Swift did leave Temple's home Moor Park (where he first came to know the child Esther Johnson) for a year, and-perhaps-upon his return he found that she had matured noticeably (the difference between ages thirteen and fourteen can sometimes be remarkable). Indeed, in his brief biography “On the Death of Mrs. Johnson,” Swift comments that "[s]he was sickly from her childhood until about the age of fifteen: But then grew into perfect health, and was looked upon as one of the most beautiful, graceful, and agreeable young women in London” (227), a statement that corroborates my sense of a sudden flowering and Swift's equally sudden awareness of a mature beauty, "only a little too fat" (227). Yes, the change seems to have come at the age of fifteen, not fourteen and not sixteen, but, as we've already seen, Swift is making a point of not counting the years. At some point in her mid-teens, Stella ceased to be a child to Swift; she became "the brightest virgin on the green," with "hair blacker than a raven, and every feature of her face in perfection" ("Death" 227).

Encoded, though somewhat scrambled, in the initial toast, then, are the details of a long friendship. As the first stanza concludes, we hear affection and reassurance in the speaker's voice: "So little is thy form declin'd; / Made up so largely in thy mind." The words might provoke a laugh, for, of course, Stella's form has not declined; it has enlarged. I think, however, the text drives us toward a gentler reading. Fat or thin, Stella is the same as always (she just thinks she's less beautiful than she was). Further, to the speaker, she will always be the same. We understand as much because the way Swift sets up the lines makes us think he is going to say "Made up so largely in my [rather than thy] mind"-as in "I still remember you as I saw you on the green at sixteen." Therefore, even though he does not say "my," the notion of a Platonic form lingers over the poem. Stella, he tells us in the biography, was well schooled-by him-in 
Platonic philosophy, as well as Epicurean, "the defects" of which "she judged very well" ("Death" 231). It is clear that the speaker wishes to convey to Stella that her appeal was never primarily physical. It was always largely her wit, that is, her mind, as their study of Plato would suggest.

The second stanza proved more difficult for me than the first. Here, biography did not help add texture and meaning as it had in the first stanza. I still envisioned Swift at the table of a birthday dinner standing to recite his poem for Stella and their guests. But his language became more private to me-more obscure. I thought, in listening to Richetti's rendition, he felt the same. To my ear, on the second verse, Richetti's voice begins in the same register as in verse one, but as he continues to recite, his tone becomes somewhat opaque, much less jovial, less teasing, more sincere. And while he may have been comfortable with what he was feeling as he read, I found it hard to perform the second verse satisfactorily on my own.

Yet the difficulty itself was instructive. What were my stumbling blocks? For one thing, a new trope enters the poem: "Oh, would it please the gods to split / Thy beauty, size, and years, and wit, / No age could furnish out a pair / Of nymphs so graceful, wise, and fair” is an oblique appeal to the love poem's conventional strategy of immortalizing the beloved's beauty in verse. It is one of the virtues of Swift's addresses to Stella that the poet does not employ that trite device, yet here he seems tempted to do so. He does not surrender to the impulse, however. Instead, he provides an almost macabre variation on the theme. The lines seem suspended in air to me. I am imagining gods picking and choosing parts from all the ages to fashion two nymphs as fair as the one Stella is, but it is an unpleasant image. My voice grew taut as I tried to say the second couplet of this stanza. But I recovered at the next couplet because I felt the speaker was back to praising the Stella before him-focusing on the lustre of her eyes and having them clearly compensate for the loss in beauty represented by the doubling of years and size. Wit, of course, is added to the serial account of Stella's doubled features, and that brought a smile to my voice as I recognized the embedded compliment.

I found the phrase "And then, before it grew too late" confusing at first. What deadline is impending? Have the gods placed temporal boundaries on this fantasy Swift has constructed? Or is the sense of "lateness" simply inherent in the occasion for the poem? I decided that the phrase was natural to the occasion-a cliché, even—and, as such, did not require special intonation. Birthdays, after all, mark the passing of time. Stella's changed shape is not permanent; she will change again and again as the years go by. But, however much she changes, Swift assures her, his admiration will remain constant and complete.

Still, the final image of the twin, thin half-lustred, half-witted Stella-nymphs and the split worshiping Swift-swains is a melancholy image for all that. Imagining the poem spoken in context, I felt a sense of relief as I envisioned the speaker turning to the full-bodied Stella whose eyes are shining in appreciation of such a fanciful poetic tribute to her lasting attractiveness and the increasing love of her friend. Even if the image of the two Swift-swains worshiping two nymphs brought to mind Esther Vanhomrigh, Stella would certainly know that on this occasion, she had Swift to herself and that in the poem she is the one with two lovers. The Stella assumed and addressed by this poem is above blatant flattery. Her eyes are alive with intelligence, wisdom, and wit as well as appreciation (in my view), and it discredits her to assume she winces 
at some perceived hostility in "dismemberment" or pouts in some fit of sullen resentment at her friend's flaws and failings, to which he, after all, draws sheepish attention.

I hear this poem as an occasional poem, and so in my effort to understand it, I dramatized it in my mind as a toast that began with a few biographical details and that ended with a flight of fancy that would have been understood by most who were familiar with Swift's imagination (after all, in a few years all of London will be celebrating Swift's experiments with "size" in Gulliver's Travels). In an email exchange I had with John Richetti as I wrote the paper I would deliver at SAMLA, I discovered that his "listening" and performing were affected by tradition and form. He notes:

Like all of Swift's poetry [Stella's Birthday, 1719] has a generic tilt, a reversal of the praise of a mistress (an old trope; see Shakespeare's "My mistress' eyes are nothing like the sun”!), but in this case made even sharper by the joke about Stella's size, twice as big at 34 as she was at 16 . But I do think you're right that the poem grows darker and like all poems praising a lover resolves itself into a poem about mortality and the need to seize the day (like Marvell's "To his Coy Mistress"). So "then before it grew too late” is indeed ominous, even if the lateness applies to both Stella and Swift.

Without imagining the "toast," then, the "reversal of the praise of mistress" tradition would yield the same feelings, and nearly the same understanding (though Richetti did say that he felt the opening of his reading too jovial at this point of his own thinking about the poem, whereas I continue to feel it appropriately jovial).

Through my experience of preparing this poem for performance, I can endorse both Ralph Cohen's sense of the poem as “teasing” (8) and Ronald Paulson's reading of it as a meditation on the relationship between "the physical and spiritual in Stella" (308). ${ }^{7}$ I thoroughly agree with Edward W. Said that the poem is one of several of Swift's written "variations on the theme of conversation ... demonstrating the peripheries at which conversation shades subtly into writing" (54). Barnett, too, notes the sense of the "Dublin social circle” in the "jocular Stella poems" (27), a reading sustained in the poem as I feel it should be performed. Perhaps, even, I can hear a little of the hostility that Ros Ballaster asserts lies behind Swift's treatment of Stella's body in the poem (173) - though, for me, the hostility would seem to be rooted in regret at the aging process and the simple material fact of decay. I see no specifically gendered aversion here.

As someone who is inclined to put on weight from time to time, I can certainly feel chagrin on Stella's behalf_-and for many years, I did just that when reading this poem. "Ouch!” I thought when reading the lines about the doubled size. "Why did he have to say that?" Carol Houlihan Flynn has reacted with similar defensiveness: "We only know about Stella's fat from Swift himself” (124). David Nokes says the lines are designed to "reduce Stella's self-esteem” (249). Still, why should we automatically assume that Stella's feelings would be hurt by reference to her size-accurate or not? In thinking it over, I have to admit that the subject of weight between close friends and relations can be a topic of affectionate commiseration, wry humor, or even affirmation of an unexpected sort. Indeed, in a period of plumpness in my thirties, I recall my grandmother observing that I'd put on weight and then adding: "it suits you." It did not, but that 
this painfully honest, fundamentally self-absorbed, and piously religious woman would lie to make me feel better about myself was actually quite touching and one of the fondest memories I have of her. And, I have long recognized that there is another point I must admit: she truly may have thought it suited me (my own sense of what I should look like notwithstanding). ${ }^{8}$ In any event, even at the time, I felt only love from my grandmother, not hostility in the slightest. Could not Stella bear reference to her weight with a similar sense of emotional nuance? I would think so. This is the woman, after all, who could hear her rival Vanessa praised as one who "inspired the Dean to write ... finely upon her" and say, with a smile, "it was well known the Dean could write finely upon a broomstick” (Johnson 332).

\section{“The Mouse’s Petition”}

In reading the occasional poetry of the past, we cannot hear with the ear of the original audience. But we can hear, if we listen, the voice of the text, and we can understand, fairly accurately if we are duly attentive, what it is saying. Of course, if the occasional poem is offered in the voice of a ventriloquist, we have additional obligations. In "performing” such a poem, we are speaking in the voice of the character, not the poet. But we are also making an effort to hear the voice behind the voice-the message, as well as the messenger. In the case of "The Mouse's Petition," we have a third obligation i.e., to hear with the ear of Joseph Priestley whom Barbauld identified as the mouse's addressee in a note to the word "Petition" in the title: "Found in the trap where he had been confined all night by Dr. Priestley, for the sake of making experiments with different kinds of air” (36n).

In testing Barbauld's poem against her stated intent, that is pleading the cause of mercy, not justice, I spent a day with this poem, as I had done with Swift's poem to Stella. My motive in this instance was similar to the one that drove my decision to perform "Stella's Birthday, 1719" at SAMLA. That is, I wanted to see if performance would "redeem" the poem in the Cavellian sense. Would voicing “The Mouse's Petition” prove that Barbauld's stated intent was, indeed, the truest reading of the poem? Or would performance reveal a text with subliminal intent and covert meaning beyond the author's conscious (or admitted) control? Either way, the poem is one I have long worried over (my interest in Barbauld being a more-than-passing one), and this essay for Aphra Behn Online provided an “occasion” for working my way through the poem to a redemptive reading, one that vindicates the author's own sense of her poem.

The first stanza of “The Mouse’s Petition” seems straightforward enough, echoing in many ways the passage in Laurence Sterne's A Sentimental Journey in which a caged starling repeats the phrase "I can't get out": "I vow" says Yorick, "I never had my affections more tenderly awakened" (95). As the last two lines of the opening quatrain suggest, Barbauld surely hoped her "pensive prisoner's prayer" would have the same effect on Priestley and other readers: "And never let thine heart be shut / Against the wretch's cries” (3-4).

The second verse, however, complicates matters by introducing the idea of a "fate" that awaits the creature at dawn. Like Pope's lamb whom "thy riot dooms to bleed to-day" (1.81), Barbauld's mouse is destined to die in the morning. But unlike Pope's creature who, is "kindly

giv’n” "blindness to the future” (1.85) and therefore spends his last minutes “skip[ping] and 
play[ing]” (1.82), “crop[ping] flowery food” (1.83), and even "lick[ing] the hand just rais'd to shed his blood” (1.84), Barbauld’s doomed victim is a nervous wreck:

For here forlorn and sad I sit

Within the wiry grate;

And tremble at th'approaching morn,

Which brings impending fate. (5-8)

The mention of "grate” resonates with the previous verse's use of "prisoner" as the mouse's name for himself. The grate seems more a jail than a cage or a trap, and the notion of execution may make us wonder what the rodent's crime has been. That will not be clear until the sixth stanza (for there is, indeed, a crime). In the third and fourth stanzas, the mouse postpones the revelation (his confession, as it were) by turning his attention to Priestley himself.

In these stanzas, the mouse amusingly demonstrates that he has profited from his residence in Priestley's household. He has learned enough of the scientist's various causes and commitments to be able to formulate arguments that make use of Priestley's own language and views. He begins coyly enough:

If e'er thy breast with freedom glow'd,

And spurn'd a tyrant's chain,

Let not thy strong oppressive force

A free-born mouse detain. (9-12)

I cannot imagine the reader who would reject the association with those who fight tyranny, but Priestley, in particular, had cause to identify with the mouse's conditional clause, for he had recently “denounced the government for attempting to 'enslave' the American colonists” in his 1769 The Present State of Liberty in Great Britain and her Colonies (McCarthy and Kraft 71 n1; Schofield 212-13). The speaker might be pressing it, however, with the suggestion that Priestley is an oppressive force detaining the "free-born mouse." After all, the "free-born Englishman" was liberal cant by this point in time (having been a "patriot phrase" during the reign of George II). Is the mouse suggesting that any degree of control is oppression, that any exercise of power, tyranny? As I found it impossible to say the phrase "free-born mouse" without a hint of irony, I had to conclude that Barbauld herself views her little speaker with some amusement.

ndeed, even the mouse seems to recognize that the political argument has fallen a little flat (or become a bit ludicrous), as in the next verse, he takes a different tack. He even signals a new beginning with the repetition of the exclamation with which he began the poem- “Oh!”- -before moving on to an argument centered on the joint theme of hospitality and humility:

Oh! do not stain with guiltless blood

Thy hospitable hearth;

Nor triumph that thy wiles betray'd

A prize so little worth. (13-16) 
But is the mouse really guiltless? And is the prize worthless? The speaker is trying desperately to argue both cases, but Priestley actually needs the small creature for his experiments (making the mouse a thing of value). And, moreover, the mouse has no legitimate claim to the hospitality he demands. What well-regulated (or even poorly regulated) home welcomes rodents?

While Barbauld's approach partakes of the beast fable, it also differs from that genre in that her narrative is set in the real world (Clute and Grant). The mouse can talk and write, but he is still a mouse - a recognized and unwelcome guest in many a house, in the same category as roaches and bugs and snakes. The next two stanzas make that point clear as the mouse reveals his relationship to the Priestley home and asks for a kind of freedom he willingly relinquished when he began poaching off the family rather than making it in the wild:

The scatter'd gleanings of a feast

My frugal meals supply;

But if thine unrelenting heart

That slender boon deny,

The cheerful light, the vital air,

Are blessings widely given;

Let nature's commoners enjoy

The common gifts of heaven. (17-24)

Still casting Priestley as hard-hearted, the mouse has begun to admit that his presence in the household may not be welcome. Interestingly, the logic has become almost syllogistic, taking two quatrains to unfold. "I just eat a little, but if you don't want me to have the crumbs from your table, please let me go into the wild, for, after all, I'm a commoner of nature and I should be able to enjoy what nature gives us.” In formal logic:

Some creatures have a right to eat in Joseph Priestley's home.

All creatures have a right to eat in nature.

I am a creature; therefore I have a right to eat in nature-but, maybe not in Joseph Priestley’s home.

Despite his seeming concession, the mouse has returned to a political reading of his situation. He is a commoner; Priestley, an aristocrat, at least an intellectual aristocrat, as the next stanza implies:

The well taught philosophic mind

To all compassion gives;

Casts round the world an equal eye,

And feels for all that lives. (25-28)

Priestley is a god of sorts, to the mouse now. Yet the little creature cannot rest easy in his dependency. He insists on a quasi-equality with the philosopher he has just praised and, in doing so, embraces a doctrine that Priestley has vociferously opposed, that of transmigration of the soul (“Mouse’s Petition” 246n): 
If mind, as ancient sages taught,

A never dying flame,

Still shifts thro' matter's varying forms,

In every form the same,

Beware, lest in the worm you crush

A brother's soul you find;

And tremble lest thy luckless hand

Dislodge a kindred mind. (29-36)

Are you a man or a mouse, Joseph Priestley?

Oh, this will not do, and even the mouse seems to realize it. Appealing to Priestley's "humanity" or sense of “duty” will not answer the mouse's end inasmuch as the mouse is not human and Priestley's job is to perform experiments for which the mouse serves a crucial, if fatal, purpose. The poem ends with the mouse's tacit admission that pity is the only answer to his problem. Politics is not the point. Hospitality is a ridiculous demand. Identification is even more absurd. The only hope resides in the goodness of Priestley's heart. The mouse ends by pleading, rather than petitioning: Could you simply see me as a participant in life, just as you are, and let me live? Who knows? Maybe one day you too will find yourself on the brink of destruction and someone will have pity on you.

Here is the mouse's final plea, in his own words:

Or, if this transient gleam of day, Be all of life we share,

Let pity plead within thy breast

That little all to spare.

So may thy hospitable board, With health and peace be crown'd; And every charm of heartfelt ease Beneath thy roof be found.

So, when destruction lurks unseen, Which men, like mice, may share, May some kind angel clear thy path And break the hidden snare. (37-48)

The most touching aspect of this ending is the mouse's generosity-his wish for health and peace in the home (which cannot include his presence) and his understanding that an act of mercy is an act of grace, not to be expected, but to be hoped for and honored should it occur.

We do not have any evidence that Anna Aikin Barbauld ever read her own poetry aloud, although I would imagine that she did so. ${ }^{9}$ If she read this poem to her friend Joseph Priestley, she would have been functioning as a herald in his court-presenting, in voice, the request left in 
writing by the little mouse. This poem is not a "toast" or a speech; it is a written petition. Yet, in the end (because it fails to make its case logically) it becomes a plea in the voice of the mouse. My sense of a performance of this poem has to do with a "Priestley" reading a manuscript that rehearses all his favorite political and scientific notions and references those he rejects as well. Behind the voice of the mouse, he "hears" the voice of his friend agreeing with him about, and challenging him on, his theories. In the final verses, though, Priestley is addressed sentimentally and sympathetically. The appeal is not proffered in the service of the mouse so much as it is advanced to remind the scientist of the feelings of all creation. And, though he may be moved to release the little creature, he will not abandon his scientific inquiry. No one-not even the mouse-is asking him to do that.

As in the Stella poem wherein I imagine a world in which friends can note weight gain without implying emotional rejection, in this poem I imagine one reminding her friend that, although science has a price and progress exacts penalties, the very necessary demands of research can yield—occasionally_to merciful actions in tribute to the sanctity of life. Attention to the structure and diction of the poem will not sustain the reading of this poem as a poem about "animal rights" in general (paceRichard Holmes). ${ }^{10}$ Instead, it must be read as clever homage to a friend's work and thought couched in a gentle, genial attempt to make him pause to consider the cost and consequences of his labor and to acknowledge as much by letting one mouse live. ${ }^{11}$

\section{[Audio of Elizabeth Kraft reading “The Mouse’s Petition”]: the_mouses_petition}

British Women Poets of the Long Eighteenth Century makes available poems with which we are unfamiliar, poems that would benefit from our and our students' attempts to voice them with full understanding of their participation in the world in which they were produced. The two poems I have "worked through" for this essay demonstrate a few strategies that could fund oral presentation of any of the poems. To undertake such a task, as I hope I have shown, is to investigate the times, the poets, the audiences, the occasion, and the interpretive tradition, as well. In explaining their choices (in writing or in discussion), students will reveal the depth of their intellectual engagement as their voicing of the poem will reflect their understanding of the text and reveal their interpretation of its meaning. 


\section{Works Cited}

Backscheider, Paula R. Eighteenth-Century Women Poets and Their Poetry: Inventing Agency Inventing Genre. Baltimore: Johns Hopkins UP, 2005. Print.

Ballaster, Ros. “Jonathan Swift, the 'Stella’ Poems.” A Companion to Eighteenth-Century Poetry. Ed. Christine Gerrard. Oxford: Blackwell, 2006. 170-83. Print.

Barbauld, Anna Letitia. “The Mouse’s Petition.” The Poems of Anna Letitia Barbauld. Ed. William McCarthy and Elizabeth Kraft. Athens: U of Georgia P, 1994. 36-37. Print.

Barnett, Louise. Jonathan Swift in the Company of Women. Oxford: Oxford UP, 2007. Print.

Bellanca, Mary Ellen. “Science, Animal Sympathy, and Anna Barbauld’s 'The Mouse’s Petition.”” Eighteenth-Century Studies 37.1 (2003): 47-67. Print. http://dx.doi.org/10.1353/ecs.2003.0057

Cavell, Stanley. Themes Out of School: Effects and Causes. Chicago: U of Chicago P, 1984. Print.

Clute, John and John Grant. "Beast Fable.” The Encyclopedia of Fantasy. New York: St. Martin’s Griffin, 1999.

Cohen, Ralph. “The Augustan Mode in English Poetry.” Eighteenth-Century Studies 1.1 (Autumn 1967): 3-32. Print. http://dx.doi.org/10.2307/3031665

Doody, Margaret Anne. “Swift and Women.” The Cambridge Companion to Jonathan Swift. Ed.

Christopher Fox. Cambridge: Cambridge UP, 2003. 87-111. Print.

Flynn, Carol Houlihan. The Body in Swift and Defoe. Cambridge Studies in EighteenthCentury Literature and Thought. Cambridge: Cambridge UP, 1990. Print. http://dx.doi.org/10.1017/CBO9780511553462

Holmes, Richard. The Age of Wonder: How the Romantic Generation Discovered the Beauty and Terror of Science. New York: Pantheon, 2008. Print.

Johnson, Samuel. "Swift." The Lives of the Poets: A Selection. Oxford World's Classics. Ed. Roger Lonsdale and John Mullan. Oxford: Oxford UP, 2006. 318-46. Print.

Krulwich, Robert. “A Mouse Asks for Mercy.” NPR. Web. 21 Apr. 2010.

McCarthy, William. Anna Letitia Barbauld: Voice of the Enlightenment. Baltimore: Johns Hopkins UP, 2008. Print. 
McCarthy, William, and Elizabeth Kraft, eds. Anna Letitia Barbauld: Selected Poetry and Prose. Ontario: Broadview, 2002.

McGann, Jerome. "Preface: Recitation Considered as a Fine Art.” Poets on Poets. Ed. Tilar Mazzeo with Doug Guerra and Matt O’Donnell. 4 Sept. 2007. Web. 5 Mar. 2009.

Mill, John Stuart. "Thoughts on Poetry and Its Varieties.” Autobiography and Literary Essays. Ed. John M. Robson and Jack Stillinger. Toronto: U. of Toronto P, 1981. 341-66. Print.

Nokes, David. Jonathan Swift, a Hypocrite Reversed: A Critical Biography. Oxford: Oxford UP, 1985. Print.

Paulson, Ronald. “Swift, Stella, and Permanence.” ELH 27.4 (Dec. 1960): 298-314. Print. http://dx.doi.org/10.2307/2872061

Perkins, David. "How the Romantics Recited Poetry." SEL 31.4 (Autumn 1991): 655-71. Print.

-. Romanticism and Animal Rights. Cambridge Studies in Romanticism. Cambridge: Cambridge UP, 2003. Print. http://dx.doi.org/10.1017/CBO9780511484421

Pope, Alexander. An Essay on Man. The Poems of Alexander Pope: A One-volume Edition of the Twickenham Text with Select Annotations. Ed. John Butt. New Haven: Yale UP, 1963. 501-47. Print.

Richetti, John. “John Richetti Reads Pope and Swift.” PennSound Classics. Web. 13 Feb. 2011.

—. Message to the author. 24 Oct. 2008. E-mail.

Said, Edward W. "Swift’s Tory Anarchy.” Eighteenth-Century Studies 3.1 (Autumn1969): 4866. Print. http://dx.doi.org/10.2307/2737698

Schofield, Robert E. The Enlightenment of Joseph Priestley: A Study of His Life and Work from 1733 to 1773. University Park, PA: Pennsylvania State UP, 1997. Print.

Sterne, Laurence. A Sentimental Journey through France and Italy. A Sentimental Journey through France and Italy and, Continuation of The Bramine's Journal. Ed. Melvyn New and W. G. Day. The Florida Edition of the Works of Laurence Sterne. Vol. 6. Gainesville: U of Florida P, 2002. Print.

Swift, Jonathan. "On the Death of Mrs. Johnson.” Jonathan Swift: Miscellaneous and Autobiographical Pieces, Fragments, and Marginalia. Ed. Herbert Davis. Oxford: Basil Blackwell, 1962. 227-36. Print.

—. "Stella’s Birthday.” Jonathan Swift: The Complete Poems. Ed. Pat Rogers. The English Poets. Gen. Ed. Claude Rawson. New Haven: Yale UP, 1983. 187. Print. 


\section{Notes}

1. John Stuart Milles famous distinction between the "overhearing" of "eloquence" and the "hearing" of "poetry" is of interest with regard to occasional poetry:

Poetry and eloquence are both alike the expression or utterance of feeling: but, if we may be excused the antithesis, we should say that eloquence is heard; poetry is overheard. Eloquence supposes an audience. The peculiarity of poetry appears to us to lie in the poet's utter unconsciousness of a listener. Poetry is feeling confessing itself to itself in moments of solitude, and embodying itself in symbols which are the nearest possible representations of the feeling in the exact shape in which it exists in the poet's mind. Eloquence is feeling pouring itself out to other minds, courting their sympathy, or endeavoring to influence their belief, or move them to passion or to action. (348)

In his language, eighteenth-century occasional poetry must be regarded as "eloquence," because it addresses a specific person for the purposes of influencing feeling, belief, or action.

2. Cavelle"s actual term is "redemptive reading," by which he means "letting ourselves be instructed by texts we care about” $(51 ; 53)$.

3. Although scholars have long discounted the "secret marriage," the relationship itself continues to provoke speculation. For a review of the dominant theories, see Barnett (3259). My favorite comment on the relationship comes from Margaret Anne Doody: "Whether it is necessary to fathom the exact nature of relationships between other people, or inspect the sheets to see if there are signs of intercourse, is arguably both rude and unnecessary” (99). Whatever its exact nature, the relationship between Jonathan Swift and Esther Johnson was grounded in an intimacy we must accept if we are to hear the birthday poems as they were meant to be heard.

4. See McCarthy 77-79.

5. We do know that each poem was well received. Priestley, we believe, released the mouse ("Mouse "s Petition" 244n), and Stella copied her 1719 birthday poem into a "small quarto volume," something she presumably would not have done had the poem displeased her (Swift, "Stella"s Birthday" 686n).

6. Richetti has continued his meditations on the subject, the topic of his current book-length project and the focus of his 2009 ASECS presidential address. For the past several years, as well, he has sponsored national and regional panels devoted to the recitation of eighteenth-century poetry and discussion about the process and experience of preparing a poem for oral delivery. 
7. In this birthday poem, the "harmony" between spirit and body is still perceptible, but as the years go on, "the spirit within endures after the exterior begins to decay" (Paulson 308).

8. I would note that Swift, too, reports Stellaes inclination to fat as a received opinion, not necessarily his own.

9. In an email communication, 17 September 2010, William McCarthy confirmed that there is no evidence of Barbauld "s performing her own works - though he believes she did read "Eighteen Hundred and Eleven" to an intimate circle of select family members and friends. As David Perkins has shown, however, for the late eighteenth/early nineteenth century, "poetry was a strongly ,temporal "e and oral art—an art realized in time by the voice" ("How the Romantics" 656). People of this age performed poetry as a matter of course. Barbauld "es skill at doing so has been documented with regard to a work not her own (the ballad, "Lenore”). Her reading “electrified” her audience in Edinburgh—and made Walter Scott a poet, by his own account (qtd in McCarthy 364-65).

10. Holmes calls the poem "perhaps the first animal-rights manifesto ever written" (246n). His argument is offered speculatively in his book. An NPR segment on The Age of Wonder, however, presents the case more sentimentally, and definitively, by deeming "The Mouse "s Petition" an "early animal rights poem” (Krulwich). Tellingly, this segment, which includes an emotional reading of part of the poem by actress Anne Bobby, violates Barbauld by casting her into a subservient role with regard to Priestley. The narrative identifies her as her friend "s "lab assistant" and "a young wife and poet," when, it was never her "job" in the Priestley household to clean the cages after the great scientist "pack[ed] up for the day," and she would not marry until 1774. Her relationship to both Priestley and his wife was that of friendship, not servitude; and one wonders why it would be important to note the fact that she was a "young wife" even if that had been the case. For an interesting, and balanced, discussion of the "animal rights" significance of both Barbauld"es poem and another famous mouse poem, Robert Burns "s "To a Mouse,” see David Perkins (Romanticism and Animal Rights 8-11). See also Bellanca.

11. Barbauld makes a very similar argument in her poem "The Caterpillar" in which she describes her home as infested with the insects and her heart touched by the one she allows to live through the general devastation required by the laws of housekeeping. 